\title{
A Comprehensive Evaluation of a Gaseous Portable Emissions Measurement System with a Mobile Reference Laboratory
}

\author{
Tanfeng Cao ${ }^{1}$. Thomas D. Durbin ${ }^{1} \cdot$ David R. Cocker III ${ }^{1}$. \\ Roland Wanker ${ }^{2}$. Thomas Schimpl ${ }^{2}$ - Volker Pointner ${ }^{2}$. \\ Karl Oberguggenberger ${ }^{2} \cdot$ Kent C. Johnson $^{1}$
}

Received: 31 December 2015 /Revised: 23 March 2016 / Accepted: 3 May 2016 /Published online: 18 May 2016

(C) Springer International Publishing Switzerland 2016

\begin{abstract}
In-lab and on-road emission comparisons are made between AVL's M.O.V.E GAS PEMS 493 system and the UCR mobile emissions laboratory (MEL), which served as a Federal Reference Method (FRM) for comparison and validation. These comparisons are made for three different heavyduty engines with $\mathrm{NO}_{x}$ emission certification levels ranging from $0.27 \mathrm{~g} / \mathrm{kWh}(0.2 \mathrm{~g} / \mathrm{hph})$ to $5.4 \mathrm{~g} / \mathrm{kWh}(4.0 \mathrm{~g} / \mathrm{hph})$. The brake-specific emissions during the Not-To-Exceed (NTE) engine operating zone are compared between the FRM and portable emission measurement systems (PEMS) to quantify the measurement uncertainty of the new commercial PEMS. Overall, the PEMS shows good correlation to the FRM and demonstrate its ability to measure a wide variety range of emission levels. The PEMS brake-specific $\mathrm{NO}_{x}\left(\mathrm{bsNO}_{x}\right)$ measurement is well-behaved with +5 to $-10 \%$ relative error over the 1.0 to $7.0-\mathrm{g} / \mathrm{kWh}$ range. Further, the relative $\mathrm{NO}_{x}$ error ranged from a +15 to $-15 \%$ over the 0.1 to $1-\mathrm{g} / \mathrm{kWh}$ range. The relative $\mathrm{NO}_{x}$ error increases sharply below $0.1 \mathrm{~g} / \mathrm{kWh}$ from $15 \%$ to more than $50 \%$ at $0.02 \mathrm{~g} / \mathrm{kWh}$. The relative error below $0.10 \mathrm{~g} / \mathrm{kWh}$ is high due to the very low $\mathrm{NO}_{x}$ emission rates that approach the detection limit of both the raw PEMS and dilute FRM measurement methods. The PEMS bsCO $\mathrm{CO}_{2}$ average bias is observed to be slightly higher than the MEL reference laboratory at $2 \%$ overall. The PEMS NMHC and $\mathrm{CO}$ emissions were on average -11.8 and $-3.6 \%$
\end{abstract}

Kent C. Johnson

kjohnson@cert.ucr.edu

1 College of Engineering, Center for Environmental Research and Technology (CE-CERT), University of California, Riverside, CA 92521, USA

2 AVL List GmbH, Hans-List-Platz 1, A-8020 Graz, Austria compared to the MEL for the 2006 engine, respectively. The main purpose of this study was to determine the measurement uncertainty of recently released PEMS in comparison with legacy and ultra-low emission modern heavy-duty vehicles.

Keywords PEMS · 40CFR1065 · Real world emissions

\section{Introduction}

The US Environmental Protection Agency (EPA) and California Air Resources Board (ARB) have implemented a series of regulations to control oxides of nitrogen $\left(\mathrm{NO}_{x}\right)$ and particulate matter (PM) emissions, from diesel engines during "in-use" conditions [1]. The purpose of these regulations is to ensure that emission standards are maintained throughout the course of the engine's useful lifetime. One of the most important US regulations with respect to controlling in-use emissions is the Not-To-Exceed (NTE) standard. The US NTE standard sets limits for gaseous and PM pollutants that are emitted during operation in a defined portion of the engine map and specifies the protocols required to make those measurements [2]. The European Union and other international agencies implemented similar in-use regulations with slightly different measurement approaches. The European Union approach considered emissions over a work-based window (WBW) $[3,4]$. In either case, portable emissions measurement systems (PEMS) are critical for the implementation of these in-use regulations.

In the USA, regulators agreed that PEMS measurement uncertainty could be larger than that for laboratory measurements and thus conducted a study to evaluate the "Measurement Allowance" (MA) for PEMS [5]. The allowance accounts for PEMS measurement uncertainty and adds to the in-use standard for a Not-To-Exceed combined standard. 
EPA, ARB, and the Engine Manufacturers Association (EMA) formed a heavy-duty in-use testing measurement allowance steering committee (HDIUT-MASC) to develop these MA values [2, 5]. The University of California at Riverside's (UCR) College of Engineering-Center for Environmental Research and Technology (CE-CERT) was part of this study and used its mobile emissions laboratory (MEL) as a Federal Reference Method (FRM) to validate the developed MAs for in-use conditions for both gaseous and PM PEMS MA programs [6, 7]. The in-use validation study found PEMS measurement uncertainties were higher during in-use conditions. In particular, $\mathrm{PEMS} \mathrm{NO}_{x}$ emissions were highly biased by as much as $0.47 \mathrm{~g} / \mathrm{hph}$, or +9 to $+25 \%$ of the measured point [7]. As a result of the MA study, a $\mathrm{NO}_{x}$ allowance of $0.60 \mathrm{~g} / \mathrm{kWh}(0.45 \mathrm{~g} / \mathrm{hph})$ was adopted for 2007 2009 MY engines, which is around $25 \%$ of the 2007 standard. The $\mathrm{NO}_{x}$ allowance for post $2010 \mathrm{MY}$ engines was found to be $0.20 \mathrm{~g} / \mathrm{kWh}(0.15 \mathrm{~g} / \mathrm{hph})$, which is over $60 \%$ of the 2010 NTE standard $[8,9]$. ARB has proposed an optional $90 \%$ reduction in $\mathrm{NO}_{x}$ emissions in California where the previously adopted MA would suggest the PEMS $0.20 \mathrm{~g} / \mathrm{kWh} \mathrm{NO}_{x}$ uncertainty for this optional regulation is greater than $650 \%$ [10]. The high PEMS measurement uncertainty suggests future HDVs operating at $90 \%$ of the $2010 \mathrm{NO}_{x}$ standard will need new PEMS tools for their in-use measurement and compliance determination.

Since the completion of the MA program, the development, evaluation, and implementation of PEMS have continued to expand. The implementation of gaseous PEMS for regulatory measurements has been studied extensively in Europe, although this work has been less focused on instrument accuracy and more focused on emissions from the WBWs, pilot implementations, and measurement of PM and particle number $[3,11,12]$. There has also been a considerable effort in the development and characterization of PEMS for the measurement of particulate matter (PM) in the USA [13-15]. Following the completion of the MA program, however, there has been less emphasis on characterizing how the accuracy of PEMS might be improving over time. During the MA program and since its conclusion, PEMS manufacturers have been continuously improving the designs of gaseous PEMS. Testing conducted by Southwest Research Institute (SwRI) near the end of the MA showed that the accuracies of gaseous PEMS improved over the course of the MA program for fixed laboratory testing [16]. Studies that have focused on in-use comparisons between FRMs and gaseous PEMS have been very limited since the conclusion of the MA program, however. With the recent implementation of more stringent on-road and non-road emission standards, the emissions levels of the new engines have dropped significantly compared to the emission levels that were evaluated during the MA program. Thus, the in-use accuracy of PEMS needs to be evaluated at current modern emission levels.
As today's engine technologies rapidly evolve, manufacturers, regulators, and scientists worldwide are looking to use PEMS to generate in-use emissions and engine performance data to aid in their research and development. AVL, an Austrian-based PEMS manufacturer, released the M.O.V.E GAS PEMS 493 in late 2011 that incorporated a number of new features to address the issues found with earlier PEMS with accuracy, repeatability, and reliability [17]. The goals of this study were to provide information on the accuracy and measurement capability of AVL's PEMS with legacy and modern HDV emission levels. This study was conducted as part of a verification testing program on this PEMS system for approval under the US heavy-duty in-use testing (HDIUT) program and to quantify the new PEMS's in-use uncertainties using UCR's MEL as the FRM. The verification program consisted of a comprehensive audit and engine testing evaluation with a FRM [18]. Additionally, UCR performed two unique in-use comparisons between the PEMS and the UCR FRM utilizing a high $\mathrm{NO}_{x}$ and a low $\mathrm{NO}_{x}$ heavy-duty on-road vehicle.

This paper presents the first in-use comparison between a PEMS and a FRM under in-use conditions with a modern heavy-duty vehicle (HDV) where emission rates were within and below the 2010 certification level of $0.3 \mathrm{~g} / \mathrm{kWh}$. Emission rates during this comparison testing reached levels $90 \%$ below the 2010 standard which allows an analysis of in-use measurement uncertainty at California's future optional standard of $0.03 \mathrm{~g} / \mathrm{kWh}$ [10]. Additionally, this research represents a comparative analysis between a recently developed state-ofthe-art PEMS and a FRM.

\section{Experimental}

\subsection{Test Engines and Vehicles}

Three correlation exercises were performed as part of the PEMS audit evaluation. One utilized UCR's engine dynamometer, the second utilized UCR's in-house 2001 Freightliner heavy-duty truck, and the third utilized a 2010 compliant SCR equipped low $\mathrm{NO}_{x}$ heavy-duty on-road HDV.

A list of the HDV engines tested and their certification ratings is shown in Table 1. The range of engines tested includes brake-specific $\mathrm{NO}_{x}\left(\mathrm{bsNO}_{x}\right)$ emission levels from $5.4 \mathrm{~g} / \mathrm{kWh}$ representing MY $2000 \mathrm{HDV}$ certifications to less than $0.3 \mathrm{~g} / \mathrm{kWh}$ representing modern MY 2010 and later HDV certifications. The selected emission levels thus provide PEMS users a comprehensive evaluation of the PEMS performance over a wide range of $\mathrm{NO}_{x}$ operating conditions. The main comparisons were based on the NTE points, where a NTE point is defined when an engine enters a predefined speed and torque zone for more than $30 \mathrm{~s}$ 
Table 1 Engine dynamometer and in-use vehicle test matrix

\begin{tabular}{|c|c|c|c|c|c|c|}
\hline Test units & Location & Test Engine & Power and Torque & ECS & $\begin{array}{l}\text { Certif. } \mathrm{NO}_{x} \\
\mathrm{~g} / \mathrm{kWh}(\mathrm{g} / \mathrm{hph})\end{array}$ & $\begin{array}{l}\text { Number } \\
\text { NTE points }\end{array}$ \\
\hline 1 & Engine lab & $\begin{array}{l}2006 \text { Cummins } \\
\text { ISM } 10.8 \text { L }\end{array}$ & $\begin{array}{l}370 \mathrm{hp} \\
1450 \mathrm{ft}-\mathrm{lb}\end{array}$ & EGR & $2.7(2.0)$ & 150 \\
\hline 2 & In-use & $\begin{array}{l}2000 \text { Caterpillar } \\
\text { C15 15.0 L }\end{array}$ & $\begin{array}{l}475 \mathrm{hp} \\
1650 \mathrm{ft}-\mathrm{lb}\end{array}$ & CRT-retrofit & $5.4(4.0)$ & 145 \\
\hline 3 & In-use & $\begin{array}{l}2011 \text { Cummins } \\
\text { ISX } 11.9 \mathrm{~L}\end{array}$ & $\begin{array}{l}425 \mathrm{hp} \\
1650 \mathrm{ft}-\mathrm{lb}\end{array}$ & $\begin{array}{l}\text { OEM } \\
\text { DOC, DPF } \\
\text { SCR }\end{array}$ & $0.3(0.2)$ & 174 \\
\hline
\end{tabular}

The 2006 Cummins engine is referred to as the 2006 CUM 10.8, the 2000 Caterpillar is denoted 2000 CAT 15, and the 2011 Cummins is denoted as the 2011 CUM 11.9

$E C S$ emissions control system, $D O C$ diesel oxidation catalyst, $D P F$ diesel particulate filter, $O E M$ original equipment manufacturer, $S C R$ selective catalytic reduction, $E G R$ exhaust gas recirculation, $C R T$ continuously regenerative trap

$[1,6,9]$. The three tests generated anywhere from 145 NTE points to 174 NTE points.

\subsection{PEMS Description}

The PEMS evaluated are the gaseous unit of AVL's Mobile On-Board Vehicle Evaluation (M.O.V.E) system. The 493 gaseous PEMS include a system controller, a post processor, and an exhaust flow meter. The AVL gaseous PEMS use heated flame ionization detection (HFID) for total hydrocarbon measurement, non-dispersive ultraviolet (NDUV) for $\mathrm{NO}$ and $\mathrm{NO}_{2}$ measurements, and non-dispersive infrared (NDIR) for carbon monoxide $(\mathrm{CO})$ and carbon dioxide $\left(\mathrm{CO}_{2}\right)$ measurements. The AVL PEMS design was based on accuracy and long-term measurement stability and includes some new features, such as internal damping, climate control, and a multi-stage water removal system [17]. The AVL 494 PM PEMS was previously validated in some earlier studies by the same MEL and, thus, was not included in this research $[14,15]$.

The PEMS were first evaluated in an engine test cell and were subjected to variations in test cell temperature, but with constant pressure and no vibration. Then the PEMS were installed on two HDVs where the PEMS were mounted outside the tractor cab and exposed to ambient conditions and onroad conditions which included vibration, barometric pressure changes with elevation, and electrical interferences possible during on-road operation. The PEMS were secured to a shock absorbing system provided by the PEMS manufacturer which was mounted to a custom frame located behind the passenger side fuel tank. The electrical power and necessary operating gases for the PEMS were provided by the UCR MEL. A PEMS weather probe was installed inside of a weather shield mounted on the rear of the cab away from any obvious heat sources. The PEMS were calibrated at the beginning and the end of the day, as per typical in-use test operating procedures. The PEMS were automatically zero checked hourly using zero air gas as recommended by the manufacturer. Measurement accuracies could be improved by hourly span calibrations, but this approach would not be representative of most in-use testing and, thus, were not performed in this comparison.

\subsection{UCR Mobile Emissions Laboratory Description}

The UCR MEL was used as the FRM for this PEMS comparison study and was the same validation laboratory used during the federal PEMS MA program, making this correlation study directly comparable to previous PEMS studies $[6,7]$. The MEL consists of a number of operating systems typically found in a stationary certification laboratory. However, the MEL is a 53-ft trailer that can be hauled under typical driving conditions and used to measure the emissions directly from the vehicle towing the MEL $[19,20]$.

The MEL is a qualified mobile reference laboratory for performing PEMS validations. A 40 CFR Part 1065 audit for the gaseous and constant volume sampler (CVS)-related measurements was successfully completed in the MEL prior to performing the correlation testing with this PEMS study and previous MA studies [6, 21]. The UCR MEL has also previously performed cross-correlations with several certification laboratories throughout the USA. In 2006, the UCR MEL has cross-correlated with SwRI on two separate trips and ARB's heavy-duty chassis laboratory [6, 21]. In addition, the UCR MEL successfully completed a blind audit by ARB as part of another research project. The MEL was operated with hourly zero and span calibrations during comparison with AVL's 493 gaseous PEMS, thus minimizing its uncertainty and reducing instrument drift, as performed during the previous MA studies [6,7].

\subsection{Interferences, Validation, and Accuracy}

The main purpose of this study was to characterize the in-use uncertainty of the latest PEMS technology for legacy and modern HDVs. Prior to conducting these tests, several steps were performed before the emission testing to characterize and quantify the PEMS measurement capabilities, including 
a successful 40 CFR Part 1065 audit [18]. The audit included NDIR interference checks, $\mathrm{NO}_{x}$ measurement interference checks (NDUV and CLD), measurement linearity, etc. for both the PEMS and MEL, respectively. This combined effort resulted in over 100 experiments (interference checks, accuracy checks, and linearity verifications) on both systems. In all cases, the comparisons showed excellent agreement where interferences and accuracies were within $2 \%$ for all measurements except exhaust flow, which had uncertainties in the range of $5 \%$ and varied by installation and application.

\section{Results}

This paper focuses on the correlation results of the gaseous PEMS with the UCR MEL, which is termed the FRM in the discussion below. Brake-specific emission factors for $\mathrm{NO}_{x}$, non-methane hydrocarbon (NMHC), $\mathrm{CO}$, and $\mathrm{CO}_{2}$ were calculated using the J1939 broadcast speed and torque values from the vehicle's electronic control module (ECM) [7]. It should be noted that the PEMS met all the 40 CFR Part 1065 requirements during the correlation testing.

\section{1 $\mathrm{NO}_{x}$ Emission Results}

The comparisons in this report are expressed in either absolute emission deltas, which are defined as the absolute difference between the PEMS and the FRM in units of grams per kilowatt-hour, or in relative deltas, which are defined as the relative error of the PEMS compared to the FRM in unit of percentages. The PEMS's $\mathrm{NO}_{x}$ deltas as a function of FRM emission level for the engine dynamometer and on-road comparisons are displayed in Fig. 1.

The 2000 MY Caterpillar engine had higher bsNO ${ }_{x}$ emission levels and showed higher bsNO ${ }_{x}$ deltas compared to the other two engines tested in this study. However, the validation

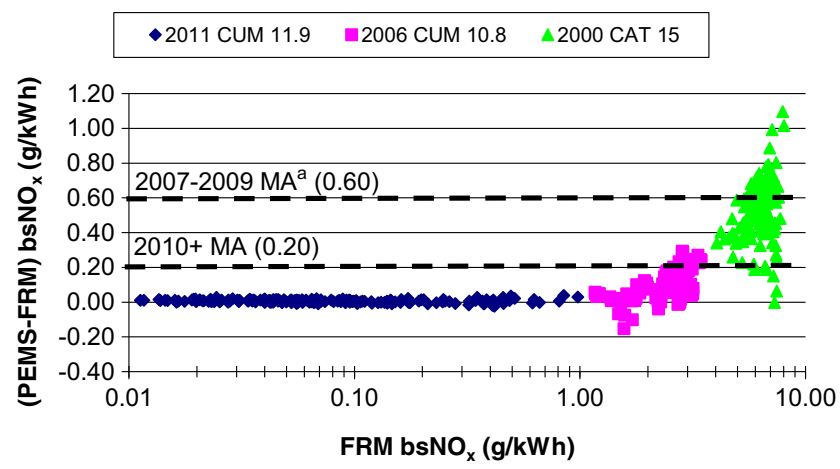

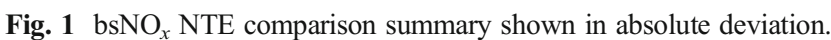
${ }^{a}$ The in-use NTE standard was based on the 2007 emission levels of 1.68 $2.68 \mathrm{~g} / \mathrm{kWh}(1.25-2.0 \mathrm{~g} / \mathrm{hph})$; thus, emissions higher than $2.68 \mathrm{~g} / \mathrm{kWh}$ are not representative of the MA of $0.60 \mathrm{~g} / \mathrm{kWh}$ shown and may exceed the MA on a difference basis. The relative error is more representative for emission rates above $2.68 \mathrm{~g} / \mathrm{kWh}$ as presented in the next figure of the ability of PEMS measurement to maintain a specific delta relative to the MA is heavily dependent on the emission level. Therefore, the relative error is more important to evaluate higher emission levels while absolute error is more important to evaluate lower emission levels (e.g., post $2010 \mathrm{MY}$ engines). The relative error of the $2000 \mathrm{MY}$ engine is approximately $5 \%$ relative error overall, similar to the $2006 \mathrm{MY}$ engine (Fig. 2).

The bsNO ${ }_{x}$ relative error for the 2000 engine and 2011 engine (above $0.10 \mathrm{~g} / \mathrm{kWh}$ ) tested in-use is similar overall to that for the 2006 engine tested on an engine dynamometer suggesting that the PEMS $\mathrm{NO}_{x}$ measurement is robust down to $0.10 \mathrm{~g} / \mathrm{kWh}$ regardless of sources (Fig. 2). PEMS $\mathrm{NO}_{x}$ relative error is observed to be approximately +5 to $-10 \%$ from 1.0 to $7.0 \mathrm{~g} / \mathrm{kWh}$ and +15 to $-15 \%$ from 0.1 to $1 \mathrm{~g} / \mathrm{kWh}$, respectively.

The PEMS $\mathrm{NO}_{x}$ relative error increased below $0.1 \mathrm{~g} / \mathrm{kWh}$ as the emission level approached the zero measurement detection limit of both the PEMS and the FRM measurement methods (Fig. 2). $\mathrm{NO}_{x}$ measurements below $0.10 \mathrm{~g} / \mathrm{kWh}$ are subjected to higher levels of uncertainty of $50 \%$ at $0.03 \mathrm{~g} /$ $\mathrm{kWh}$. Differences in $\mathrm{NO}_{x}$ emissions at such low levels could be due to several different factors. There is a fundamental difference between the NDUV and chemiluminescence methods for $\mathrm{NO}_{x}$ measurements. Chemiluminescence detection method is based on the amount of light generated via a chemiluminescence reaction of $\mathrm{NO}$ as it reacts in an ozone atmosphere to form $\mathrm{NO}_{2}$. The NDUV measurement method is based on the absorption of UV radiation from a broadband UV source to quantify the amount of $\mathrm{NO}_{x}$ in a given sample.

For NDUV, the $\mathrm{NO}$ and $\mathrm{NO}_{2}$ spectroscopy signal occurs during the very large water wavelength in addition to other smaller contributing signals such as sulfur compounds. The water signal is so large in relationship to the $\mathrm{NO}$ and $\mathrm{NO}_{2}$ signals that special processing is required to quantify the nitrogen compounds on top of this signal. During near-zero measurements, the large water signal makes the nitrogen species signal hard to detect and thus causes larger variability at

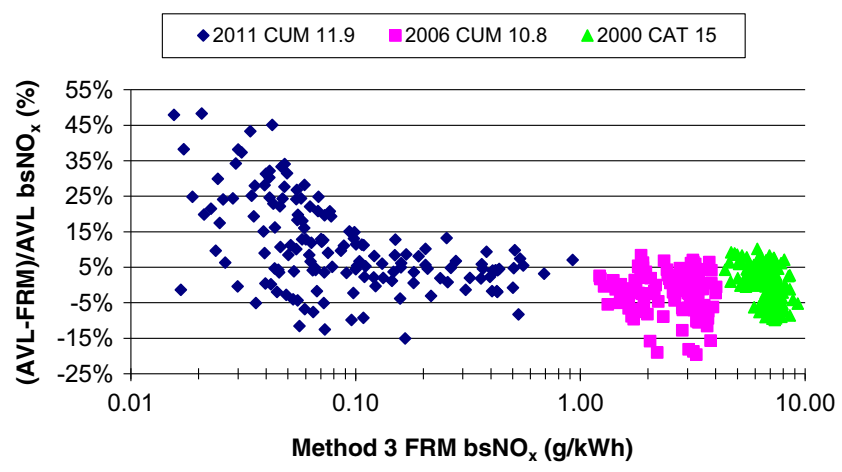

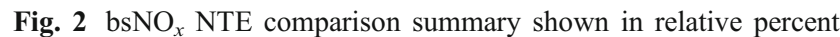
deviation 
zero. Thus, there is not an interferent issue like CLD, but there is a signal detection response issue resulting from other species. The CLD measurement method, on the other hand, has interferences from water and $\mathrm{CO}_{2}$ where these molecules block light transmission during the measurement process. The CLD interferences are on the order of $1-2 \%$ for large water and $\mathrm{CO}_{2}$ concentrations at high and low signal level; thus, the magnitice does not change at low NO concentrations. In general, radiation absorption spectroscopy of NDUV analyzers typically is less sensitive than the light generated in the chemiluminescence reaction in CLD analyzer near-zero measurement quantification.

Analyzer drift also becomes more critical for measurements at such low levels. The PEMS manufacturer-specified drift criteria of the NDUV analyzer is $2 \mathrm{ppm}$ per $8 \mathrm{~h}$ for both $\mathrm{NO}$ and $\mathrm{NO}_{2}$, which equates to $4 \mathrm{ppm} / 8 \mathrm{~h} \mathrm{NO}_{x}$ [17]. Based on the in-use zero drift evaluation of this study, the NDUV analyzer showed a max $1.67 \mathrm{ppm}$ drift at the 90th percentile (Table 3). The lowest $\mathrm{NO}_{x}$ measurements observed by the PEMS are near the instrument drift specifications and possibly the PEMS detection limit during in-use testing. It should be noted that analyzer drift is expected to become an even more critical issue if there are further reductions in the $\mathrm{NO}_{x}$ standard from 0.2 to $0.02 \mathrm{~g} / \mathrm{hph}$. One of the major limiting factors under those conditions will be the analyzer drift specification under CFR 1065.550 which requires the drift to be within $\pm 4 \%$ of the standard. This represents a $0.008 \mathrm{~g} / \mathrm{hph}$ drift allowance for a $0.2-\mathrm{g} / \mathrm{hph}$ standard, but would be lowered to a $0.0008-\mathrm{g} / \mathrm{hph}$ drift allowance for a $0.02-\mathrm{g} / \mathrm{hph}$ standard. It is expected that such drift specifications could be difficult to meet not only for PEMS but also for laboratory type analyzers.

\subsection{NMHC and CO Emissions Summary}

The NMHC and $\mathrm{CO}$ emission deltas were well below their respective MAs for all three vehicles tested. The relative error was large for NMHC and $\mathrm{CO}$ due to the very low emission levels for the ECS-equipped diesel engines where these emissions were on average below 0.03 and $0.02 \mathrm{~g} / \mathrm{kWh}$ for $\mathrm{CO}$ and NMHC, respectively. Thus, at these very low values, relative error is not an appropriate comparison. For the 2006 engine, which did not have an ECS, the PEMS NMHC and CO emissions were on average -11.8 and $-3.6 \%$ compared to the MEL. During the previous MA study, CO and NMHC emission levels were low for all the evaluations; thus, NMHC and $\mathrm{CO}$ were never investigated for the PEMS ability to make these measurements. During the MA study, it was considered that $\mathrm{CO}$ and $\mathrm{NMHC}$ would not contribute to the overall compliance issue and was, thus, not pursued given ECSs would be found on most modern engines. Thus, the results here do show a perspective on PEMS ability for $\mathrm{CO}$ and $\mathrm{NMHC}$ which is in good agreement with the FRM.

\section{3 $\mathrm{CO}_{2}$ Emissions and Exhaust Flow Summary}

The bsCO $\mathrm{CO}_{2}$ relative error between the PEMS and the FRM for both engine dynamometer and in-use showed the highest positive deviation $(+1.9 \%)$ and the in-use vehicles with lower bias $(-2.3 \%$ for MY 2011 engine and $+1.8 \%$ for the MY 2000 engine). The range of $\mathrm{bsCO}_{2}$ deviations varied from +10 to $-5 \%$ for all tests (Fig. 3). The bsCO $\mathrm{CO}_{2}$ deviations are attributed to uncertainties in exhaust flow measurement.

The PEMS exhaust flow relative error ranged from +10 to $-6 \%(+2 \%$ overall) for all the comparison tests (Fig. 4). The FRM exhaust flow is calculated by the difference between the two CVS venturis (total flow minus dilute flow) in the CVS system. The FRM venturis are accurate to within $\pm 2 \%$, are routinely verified by propane verifications ensuring robust measurement, and have been used for comparison in the previous MA studies $[6,7,14,15,21]$.

The FRM diluted venturi exhaust flow calculation is a very stable and reliable measurement on an integrated NTE basis and is not subject to the rapid transients that occur in the raw exhaust. The PEMS exhaust flow is measured using differential pressures sensors corrected for density using the static pressure and temperature in the exhaust line. It is difficult to accurately estimate the exhaust density because of the rapid temperature changes observed in the exhaust. Additionally, the measured dynamic pressure must be correlated with exhaust flow using a constant correction factor $K$ as part of the Bernoulli equation that the flow measurement is based on. This $K$ constant is a function of Reynolds number $(R e)$ and thus impacted by uncertainty in exhaust parameters. More analysis outside the scope of this work is required to understand these differences; the magnitude of these uncertainties is in the order of $\pm 10 \%$.

\subsection{Measured Absolute Concentration}

NTE brake-specific emissions and concentrations for $\mathrm{NO}_{x}$, $\mathrm{CO}, \mathrm{NMHC}$, and $\mathrm{CO}_{2}$ are summarized in Table 2 for both the PEMS and FRM. The concentrations represent average measured values where the FRM is for diluted CVS measurements while the PEMS is for raw exhaust measurements.

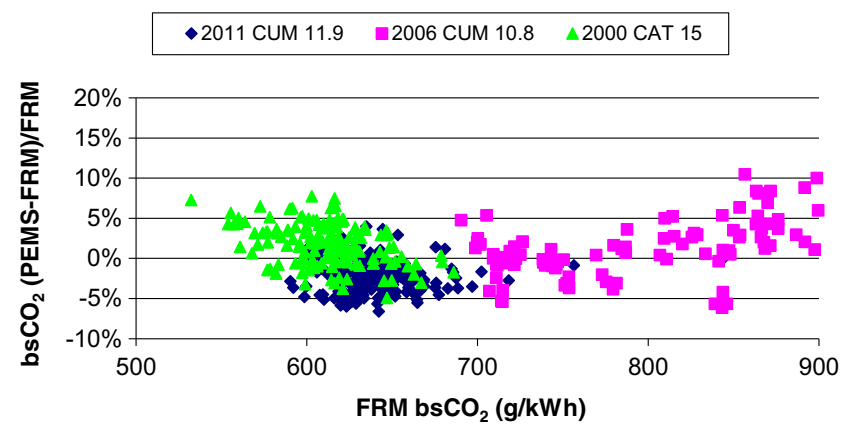

Fig. 3 Percent $\mathrm{bsCO}_{2}$ deviation between PEMS and FRM 


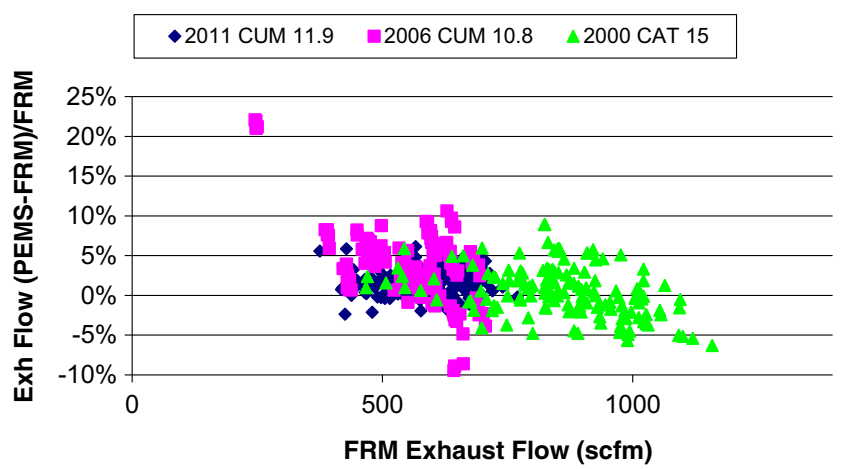

Fig. 4 Relative error in exhaust flow measurement (scfm) between the PEMS and FRM

Therefore, the concentrations between the PEMS and the FRM are not expected to be similar; rather, they provide a magnitude of the concentrations of each species measured. The MY 2000 vehicle had the highest $\mathrm{NO}_{x}$ concentrations, the MY 2011 vehicle had the highest $\mathrm{CO}_{2}$ concentrations, and the MY 2006 engine had the highest CO and NMHC concentrations. The THC and CO concentrations were only a few parts per million for both the MY 2000 and MY 2011 vehicles. The average $\mathrm{NO}_{x}$ concentrations were lowest for the 2011 vehicle and averaged 19 ppm for the PEMS and 5 ppm for the FRM. The PEMS correlated well with the FRM over the wide range of average emission concentrations for the three engines in this study.

\section{PEMS In-use Experience}

This section addresses additional issues related to the applicability of the AVL PEMS system for on-road applications. These observations are based on the PEMS installation and in-use testing for the two on-road vehicles, as discussed previously. The additional environmental conditions to be considered for in-use testing include variations in temperature, humidity, pressure, and vibration level.

\subsection{Temperature, Humidity, Pressure, and Vibration Affects}

A few past PEMS studies have suggested that PEMS are exposed to wider temperature extremes than typical ambient temperatures during in-use applications due to its exposure to different environmental conditions [21, 22]. This can in turn lead to measurement failures/issues. No additional noticeable drift of the PEMS analyzer or operational issues were encountered during in-use operations due to temperature, humidity, pressure, and vibration variations. The PEMS were operated in ambient temperatures ranging from 9 to $29^{\circ} \mathrm{C}$, in ambient relative humidities ranging from 20 to $90 \%$, and at elevations ranging from sea level to $1500 \mathrm{~m}$. Although ambient variations were not extreme, the gaseous PEMS are subjected to much higher temperatures when it is installed on the vehicle due to direct sun radiation, radiation from the engine, and low-speed/stationary operation from test vehicle, with the PEMS itself heating up to $38^{\circ} \mathrm{C}$ under very warm ambient conditions [6].

\subsection{Analyzer Drift}

Determining analyzer drift is critical for stable and repeatable emission measurements. The 40 CFR Part 1065 requirements include an analyzer drift limit that requires a PEMS test to be repeated if the analyzer drift-corrected brake-specific value exceeds $\pm 4 \%$ of the uncorrected value or the applicable emission standard, whichever is greater. Brake-specific drift is a complex calculation based on spans, zeros, and work done during the given test interval which do not reflect the absolute analyzer concentration drift of the given PEMS system. Since AVL only published the absolute zero drift data over an 8-h period, Table 3 compared the PEMS and FRM zero drift data from this study against the published reference values. In-use operation subjects to greater vibration and changes in barometric pressure and temperature that may increase PEMS

Table 2 Averaged concentration levels and bsEmission level measured by FRM and PEMS

\begin{tabular}{|c|c|c|c|c|c|c|c|c|c|}
\hline \multirow[t]{2}{*}{ Vehicle/engine } & \multicolumn{5}{|c|}{ Averaged emission concentrations } & \multicolumn{4}{|c|}{ bsEmissions (g/kWh) } \\
\hline & Test & $\mathrm{CO}$ ppm & $\mathrm{CO}_{2} \%$ & $\mathrm{NO}_{x} \mathrm{ppm}$ & THC ppm & $\mathrm{CO}$ & $\mathrm{CO}_{2}$ & $\mathrm{NO}_{x}$ & NMHC \\
\hline 2006 CUM 10.8 & PEMS & 79.8 & 7.0 & 191.8 & 52.4 & 0.582 & 867 & 2.54 & 0.212 \\
\hline 2006 CUM 10.8 & FRM & 24.4 & 2.0 & 53.7 & 13.6 & 0.660 & 851 & 2.43 & 0.220 \\
\hline 2000 CAT 15 & PEMS & 16.6 & 7.5 & 799.0 & 6.4 & 0.086 & 622 & 6.87 & 0.016 \\
\hline 2000 CAT 15 & FRM & 3.7 & 2.5 & 247.4 & 2.2 & 0.056 & 611 & 6.36 & -0.0028 \\
\hline 2011 CUM 11.9 & PEMS & 0.5 & 8.9 & 19.1 & 1.2 & 0.001 & 622 & 0.145 & 0.002 \\
\hline 2011 CUM 11.9 & FRM & 2.1 & 2.7 & 5.1 & 1.3 & 0.026 & 638 & 0.139 & -0.0006 \\
\hline
\end{tabular}

Note the average concentrations for the FRM are based on dilute measurements and raw measurements for the PEMS. Thus, the concentrations are not meant to be compared but used to show a comparative measurement level for the overall comparison 
Table 3 Statistical summary of PEMS and FRM zero drift results during the comparison

\begin{tabular}{|c|c|c|c|c|c|c|c|c|c|c|}
\hline \multirow[b]{2}{*}{ Limit $^{b}$} & \multicolumn{2}{|c|}{ Number of zeros } & \multicolumn{2}{|l|}{$\begin{array}{l}\mathrm{CO}_{2} \\
\text { vol } \%\end{array}$} & \multicolumn{2}{|l|}{$\begin{array}{l}\mathrm{CO} \\
\mathrm{ppm}\end{array}$} & \multicolumn{2}{|l|}{$\begin{array}{l}\mathrm{NO}_{x} \\
\mathrm{ppm}\end{array}$} & \multicolumn{2}{|l|}{$\begin{array}{l}\text { THC } \\
\text { ppmC }\end{array}$} \\
\hline & PEMS & FRM & $\begin{array}{l}\text { PEMS }^{\mathrm{a}} \\
0.1 / 8 \mathrm{~h}\end{array}$ & $\begin{array}{l}\text { FRM } \\
0.03 / 24 \mathrm{~h}\end{array}$ & $\begin{array}{l}\text { PEMS } \\
20 / 8 \mathrm{~h}\end{array}$ & $\begin{array}{l}\text { FRM } \\
2 / 24 \mathrm{~h}\end{array}$ & $\begin{array}{l}\text { PEMS } \\
2 / 8 \mathrm{~h}\end{array}$ & $\begin{array}{l}\text { FRM } \\
3 / 24 \mathrm{~h}\end{array}$ & $\begin{array}{l}\text { PEMS } \\
1.5 / 8 \mathrm{~h}\end{array}$ & $\begin{array}{l}\text { FRM } \\
1.5 / 24 \mathrm{~h}\end{array}$ \\
\hline Dyno. ave. & 16 & 14 & 0.00 & -0.001 & 7.8 & -1.4 & 0.77 & 0.03 & 3.1 & 0.1 \\
\hline Dyno. stdev. & & & 0.00 & 0.005 & 4.0 & 0.7 & 0.47 & 0.06 & 1.9 & 1.0 \\
\hline Dyno. 50th & & & 0.00 & 0.000 & 9.8 & -1.6 & 0.91 & 0.03 & 3.6 & 0.3 \\
\hline Dyno. 90th & & & 0.00 & 0.001 & 10.9 & -0.4 & 1.19 & 0.04 & 5.4 & 1.1 \\
\hline In-use ave. & 49 & 35 & 0.00 & 0.000 & 10.5 & -0.9 & 0.26 & 0.09 & 1.2 & 0.6 \\
\hline In-use stdev. & & & 0.00 & 0.002 & 18.0 & 0.8 & 1.53 & 0.14 & 1.8 & 0.9 \\
\hline In-use 50th & & & 0.00 & 0.000 & 3.7 & -0.9 & 0.70 & 0.01 & 0.2 & 0.0 \\
\hline In-use 90th & & & 0.00 & 0.002 & 47.3 & 0.0 & 1.67 & 0.29 & 4.4 & 1.9 \\
\hline
\end{tabular}

${ }^{\mathrm{a}}$ The PEMS $\mathrm{CO}_{2}$ zero drift was small and only recorded to two decimal points and is thus shown as zeros

${ }^{\mathrm{b}}$ The zero limit are pushed values from AVL 493 and CAI 600 series specifications (analyzer used in FRM)

analyzer drift compared with stationary laboratory conditions. The AVL M.O.V.E's PEMS zero drift was evaluated during 1 day of engine dynamometer testing and 4 days of in-use testing. The testing intervals ranged from 6 to $8 \mathrm{~h}$ per day.

The average, standard deviation, 50th percentile, and 90th percentile statistics for the 16 in-lab and 49 in-use zero deltas for the PEMS and FRM are shown in Table 3. The limit values shown were published values from product specifications. PEMS zero calibration was only performed at the beginning of each day, with subsequent zeros audits done once per hour thereafter, as part of its standard operating procedures. For the FRM, on the other hand, zero and span calibrations were done before and after each test cycle, as part of its standard operating procedures. Thus, to provide a fair comparison to the PEMS, the FRM zero results are shown as the zero deviations from the first calibration of each test day. Overall, the FRM showed significantly less zero drift compared to the PEMS due to the more frequent calibration (hourly) as well as the more accurate and stable overall sampling system.

\section{Overall Discussion}

The goal of this study was to provide insight into the capabilities of a PEMS representing the latest commercially available technology for making measurements at today's ultra-low emissions levels. Overall, the AVL's M.O.V.E GAS PEMS 493 system met and exceeded the verification acceptance criteria for in-use emission measurements. The results from this study showed that the latest PEMS have evolved over time and have similar accuracies to those of fixed laboratories for pre-2010 emission levels. Further, PEMS are now more versatile in-use applications compared to the fixed reference laboratories, which are much larger in size and cost.
The correlation between the PEMS and FRM depends on the emission level and the specific pollutant. The PEMS brake-specific $\mathrm{NO}_{x}\left(\mathrm{bsNO}_{x}\right)$ measurement is wellbehaved with +5 to $-10 \%$ relative error over the 1.0 to $7.0-\mathrm{g} / \mathrm{kWh}$ range. Further, the relative $\mathrm{NO}_{x}$ error ranged from a +15 to $-15 \%$ over the 0.1 to $1-\mathrm{g} / \mathrm{kWh}$ range. The relative $\mathrm{NO}_{x}$ error increases sharply below $0.1 \mathrm{~g} / \mathrm{kWh}$ from $15 \%$ to more than $50 \%$ at $0.02 \mathrm{~g} / \mathrm{kWh}$. The relative error below $0.10 \mathrm{~g} / \mathrm{kWh}$ is high due to the very low $\mathrm{NO}_{x}$ emission rates that approach the detection limit of both the raw PEMS and dilute FRM measurement methods. In general, the PEMS have relatively high accuracy for higher $\mathrm{NO}_{x}$ emission levels down to $0.1 \mathrm{~g} / \mathrm{kWh}$ where the PEMS measured nominal $\mathrm{NO}_{x}$ concentration is between 10 and $1000 \mathrm{ppm}$. However, for the ultra-low bsNO $\mathrm{N}_{x}$ emission levels below $0.1 \mathrm{~g} / \mathrm{kWh}$, the PEMS started to lose accuracy as the very low $\mathrm{NO}_{x}$ concentrations approaches its inuse analyzer drift. The PEMS ability to measure $\mathrm{NO}_{x}$ and the proposed optional $\mathrm{NO}_{x}$ emission regulations of $0.03 \mathrm{~g} /$ $\mathrm{kWh}$ (5 ppm raw and less than $1 \mathrm{ppm}$ dilute) will be a challenge with the latest PEMS and may have uncertainties of $\sim 50 \%$ at $0.03 \mathrm{~g} / \mathrm{kWh}$ as evaluated in this study.

The $\mathrm{bsCO}_{2}$ emissions agreed to within $2 \%$ overall, with the measurement differences being largely related to uncertainties in exhaust flow measurements. The PEMS exhaust flow measurement is subject to greater variations due to the more transient nature of the raw exhaust PEMS measurements. The PEMS NMHC and $\mathrm{CO}$ emissions were on average -11.8 and $-3.6 \%$ compared to the MEL for the 2006 engine, respectively. The PEMS and the FRM NMHC and CO emissions were both relatively similar and typically below $0.05 \mathrm{~g} / \mathrm{kWh}$ for both pollutants for the exhaust aftertreatmentequipped engines. 


\section{References}

1. Federal Register: control of emissions of air pollution from new motor vehicles: in-use testing for heavy-duty diesel engines and vehicles, Federal Register, vol. 70 No. 113 (2005)

2. 40 CFR 86.1370-2007, Not-To-Exceed test procedures, 65 Federal Register 59958, (2000)

3. Provenza, A., Bonnel, P., Weiss, M., Perujo, A.: In-use emissions testing developments in the new and future European motor vehicle emissions regulations, presentation at the 2nd UCR PEMS conference and workshop, Riverside, CA (2012).

4. Shade, B., Carder, D., Thompson, G., Gautam, M.: A work-based window method for calculating in-use brake-specific $\mathrm{NO}_{\mathrm{x}}$ emissions of heavy-duty diesel engines. SAE Int J Engines 1(1), 778793 (2009). doi:10.4271/2008-01-1301

5. U.S. Environmental Protection Agency, Determination of PEMS measurement allowances for gaseous emissions regulated under the heavy-duty diesel engine in-use testing program. Revised Final Report EPA420-R-08-005. United States Environmental Protection Agency, Arlington, USA, 2008.

6. Miller, J.W., Durbin, T.D., Johnson, K.J., Cocker, D.R., III, evaluation of portable emissions measurement systems (PEMS) for inventory purposes and the not-to-exceed heavy-duty diesel engine regulations; final report for the California Air Resources Board, 2006.

7. Johnson, K.C., Durbin, T.D., Cocker III, D.R., Miller, W.J., Bishnu, D.K., Maldonado, H., Moynahan, N., Ensfield, C., Laroo, C.A.: On-road comparison of a portable emission measurement system with a mobile reference laboratory for a heavy duty diesel vehicle. Atmos Environ 43, 2877-2883 (2009)

8. Feist, M.D., Sharp, C.A., Spears, M.W.: Determination of PEMS measurement allowances for gaseous emissions regulated under the heavy-duty diesel engine in-use testing program part 1 - project overview and PEMS evaluation procedures. SAE Int J Fuels Lubr 2(1), 435-454 (2009)

9. Sharp, C., Feist, M., Laroo, C., Spears, M.: Determination of PEMS measurement allowances for gaseous emissions regulated under the heavy-duty diesel engine in-use testing program part 3 - results and validation. SAE Int J Fuels Lubr 2(1), 407-421 (2009). doi:10. 4271/2009-01-0938

10. Air Resources Board. Update on California's heavy duty truck program: past, present, and future, October 24, 2014. Presentation to the South Coast Air Quality Management District (SC AQMD), http://www.arb.ca.gov/board/books/2014/102414/14-8-9pres.pdf
11. Rubino, L., Bonnel, P., Hummel, R., Krasenbrink, A., Manfredi, U., de Santi, G.: On-road emissions and fuel economy of light duty vehicles using PEMS: chase testing experiment. SAE Int J Fuels Lubr 1(1454e), 1468 (2009)

12. Rubino, L., Bonnel, P., Krasenbrink, A., Carriero, M., Kubelt, J., Fumagalli, I., Montigny, F., De Santi, G.: Development of an official test method for on-board PM measurements from heavy-duty diesel engines in the European Union, SAE International, 2007, $1567-1578$.

13. Boucher, T.L., Khalek, I.A., Laroo, C.A., Bishnu, D.K.: Determination of the PEMS measurement allowance for PM emissions regulated under the heavy-duty diesel engine in-use testing program. SAE Int J Engines 5, 1371-1386 (2012)

14. Johnson, K.C., Durbin, T.D., Jung, H., Cocker III, D.R., Giannelli, R., Bishnu, D.: Quantifying in-use PM measurements for heavy duty diesel vehicles. Environ Sci Technol 45, 6073-6079 (2010)

15. Khan, M.Y., Johnson, K.C., Durbin, T.D., Jung, H., Cocker III, D., Bishnu, D., Giannelli, R.: Characterization of PM-PEMS for in-use measurements - validation testing for the PM-PEMS measurement allowance program. Atmos Environ 55, 311-318 (2012)

16. Bougher, T., Khalek, I., Trevitz, S., Akard, M.: Verification of a gaseous portable emissions measurement system with a laboratory system using the Code of Federal Regulations Part 1065, SAE Technical Paper 2010-01-1069, 2010, doi:10.4271/2010-01-1069

17. AVL M.O.V.E GAS PEMS 493 user manual.

18. Johnson, K., Cao, T., Durbin, T.D., Oberguggenberger, K., Wanker, R., Schimpl, T., Pointner, V.: Comprehensive evaluation of AVL's 1065 compliant gaseous PEMS, presentation at the 22nd CRC OnRoad Vehicle Emissions Workshop, San Diego, CA, 2012.

19. Cocker, D.R., Shah, S.D., Johnson, K.C., Miller, J.W., and Norbeck, J.M.: Development and application of a mobile laboratory for measuring emissions from diesel engines. 1. Regulated gaseous emissions. Environ. Sci. Technol. 38, 2182 (2004a) http:// eprints.cert.ucr.edu/510/

20. Cocker, D.R., Shah, S.D., Johnson, K.C., Zhu, X., Miller, J.W., and Norbeck, J.M.: Development and application of a mobile laboratory for measuring emissions from diesel engines. 2. Sampling and toxics and particulate matter. Environ. Sci. Technol. 38, 6809 (2004b) http://eprints.cert.ucr.edu/511/

21. Johnson, K., Durbin, T.D., Jung, H., Cocker, D.R., Yusuf Khan, M.: Validation testing for the PM-PEMS measurement allowance program. Final report by UC Riverside to the California Air Resources Board under Contract No. 07-620 (2010)

22. Squire, J.: In-use testing experiences, presentation at the 1st UCR PEMS Workshop, Riverside, CA (2011) 